\title{
Investigation of gcat gene and antibiotic resistance pattern of Aeromonas hydrophila isolated from hemorrhagic septicemia's cases in fish farms
}

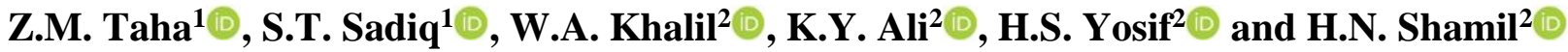 \\ ${ }^{1}$ Department of Pathology and Microbiology, ${ }^{2}$ Department of Medicine and Surgery, College of Veterinary Medicine, Duhok \\ University, Duhok, Iraq
}

\begin{tabular}{l} 
Article information \\
\hline Article history: \\
Received April 5, 2020 \\
Accepted May 14, 2020 \\
Available online March 15, 2021 \\
\hline Keywords: \\
Aeromonas hydrophila \\
Haemorrhagic septicaemia \\
Molecular detection \\
Antimicrobial resistance \\
\hline Correspondence: \\
Z.M. Taha \\
zananvete@yahoo.com
\end{tabular}

Article information

Article history:

Available online March 15, 2021

Keywords:

Aeromonas hydrophila

Haemorrhagic septicaemia

Molecular detection

Correspondence:

zananvete@yahoo.com

\begin{abstract}
The significance of Aeromonas hydrophila concerning hemorrhagic septicemia in aquaculture farms production in Duhok province, Iraq was investigated. Antibiotic-resistant profiles of isolates were also investigated with 8 antibiotics. Bacterial isolates were identified by using morphological and biochemical tests and confirmed molecularly by amplification of gcat gene. Out of 25 examined fish, only 19 fish were harbored A. hydrophila. Twenty-four $A$. hydrophila strains were isolates from 100 organ samples. Ninety-six percentages of the isolates were resistant to each of the imipenem and gentamicin, followed by doxycycline 92\%, ciprofloxacin and trimethoprimsulfamethoxazole $88 \%$, norfloxacin $58 \%$ and ceftriaxone $33 \%$. None were resistant to levofloxacin. Eighty-eight percentages were multiple antibiotics resistant. The high isolation rate of $A$. hydrophila in our study indicates that this species was the major cause of the outbreak in hemorrhagic septicemia's cases in our area affecting carp farms and the high rate of resistance should be considered as these isolate can serve as a resistance source for human being during food series and make great challenge for their therapeutic opportunity.
\end{abstract}

DOI: 10.33899/ijvs.2020.126876.1405, (C2021, College of Veterinary Medicine, University of Mosul.

This is an open access article under the CC BY 4.0 license (http://creativecommons.org/licenses/by/4.0/).

\section{Introduction}

The largest and most dangerous form of diseases affecting fish production is the bacterial infections, which account for $80 \%$ of fish mortality (1). In turn, this would adversely affect aquaculture (2). Aeromonas hydrophila is considered the primary cause of septicemia disease, including carp, tilapia, perch, catfish, salmon, and many other freshwaters and marine species (3). The marked clinical signs that seen on the abdominal wall and at the base of fins are congestion and hemorrhage as well as scale erosion at all body surfaces. While the prominent post mortem lesions are highly congested internal organs, ascitic fluid build-up in the abdominal cavity and swollen kidney and spleen (2). In addition, a variety of human illnesses have involved by $A$. hydrophila, it causes a broad spectrum of infections (gastroenteritis, septicemia, meningitis, endocarditis) in humans, often in immune-compromised hosts (4). A. hydrophila is easy to grow on standard laboratory enteric media and produces $\beta$-hemolysis on blood agar with grey, flat, round and shiny colonies about 2.0-3.0 $\mathrm{mm}$ in diameter, ability to grow on MacConkey agar with non-lactose fermentation and they are oxidase-positive $(5,6)$. Different reports have revealed that $A$. hydrophila is widely antibiotic-resistant. Considerations, including the indiscriminate overuse of antibiotics in fisheries are responsible for this. This contributes to high selection pressure in bacteria to develop resistance through a variety 
of mechanisms such as genetic mutation and horizontal gene transfer. This is a public and marine health hazard (7).

Little information is available on the fact that is it $A$. hydrophila regarded as the primary cause of hemorrhagic septicemia in fish as well as antibiotic resistance rate of $A$. hydrophila from clinical cases of fish suffering from hemorrhagic lesions in all around the world. The present study was intended to assess the accurate rate of $A$. hydrophila incidence as a causal agent of septicemias in different fish farms in Duhok city and also to assess their resistant rate against different antibiotics that most commonly used for therapeutic purposes against this bacterium in fish farms and human being.

\section{Materials and methods}

\section{Sample collection}

The sample collection process and the choosing of sample types, was carried out according to Aboyadak, (2) and Hassan et al. (8). Samples were taken from 5 carp fish farms (Agricultural 1, 2 and 3, Mosul dam and one pond in Xhanke Village) with symptoms of septicemia, which include skin hemorrhage with hemorrhagic skin ulcers and de-pigmented zones in the skin, and necropsy for internal organ lesions including extreme congestion and internal organ hemorrhage, enlarged liver and gall bladder. Each dead fish was picked in a separate sterile labeled plastic bag and transported to the laboratory in icebox. From each fish, four different samples were taken from heart blood, liver, kidney tissues, and hemorrhagic or ulcerative area on the skin. The sampling from each part of the fish lesion was carried out under strict sterile conditions to prevent contamination with normal flora, in which bacteria were isolated with a sterile loop from each organ of each fish. Four samples from each fish organ lesions were pooled to make one sample for testing. From 25 collected fish, a total of 100 organ lesion samples were taken.

\section{Isolation and identification of Aeromonas hydrophila by phenotypic methods}

Each loop sample at the collection time was directly put into tubes containing $10 \mathrm{ml}$ of brain heart infusion broth (HiMedia, India) or tryptic soy broth (Lab M, UK) and incubated at $37^{\circ} \mathrm{C}$ for $20-24$ hrs., as a pre-enrichment step (8). One to two loopful of pre-enrichment broth was inoculated on to blood agar supplemented with $7 \%$ sheep blood and incubated as previous. Beta-haemolytic 2-3 mm colonies were directly sub-cultured onto MacConkey agar and incubated as previously. Pale (non lactose fermenter) colonies of Aeromonas hydrophila were presumptively identified by Grams stain, indole production test, oxidase test, catalase test and urease test $(5,6)$. Colonies from positive samples were directly preserved at $-20^{\circ} \mathrm{C}$ as stock culture in tubes containing brain heart infusion broth with $25 \%$ glycerol (9). The final confirmation was carried out by PCR amplification of gcat (glycerophospholipidcholesterolacyltransferase) gene which is common for Aeromonas hydrophila (10).

\section{DNA extraction and detection of gcat gene by PCR amplification}

DNA samples were extracted by thermal extraction method according to Taha and Yassin (11). From stock culture $100 \mu \mathrm{l}$ was inoculated onto MacConkey agar and incubated as previous. From MacConkey agar 2-3 pure (similar morphology) colonies were chosen and mixed with $200 \mu \mathrm{l}$ of sterile double distilled water in a $1.5 \mathrm{ml}$ tube. For at least $15 \mathrm{~s}$, the mixture was vortexed and directly heated at $95^{\circ} \mathrm{C}$ for $10 \mathrm{~min}$; the samples then cooled directly by ice, the cooled suspension was centrifuged. One hundred fifty $\mu 1$ supernatant was used as a template DNA for PCR. The purity and concentration of extracted DNA were examined using a nano drop (Thermo Scientific, USA) (12). The extracted DNA samples were stored under freezing (-20) until used as DNA templates for PCR analysis (13). To identify the $A$. hydrophila, gcat gene was amplified as potential markers of detection (10). The gcat-PCR amplification was made in a total volume of $25 \mu \mathrm{l}$ containing $12.5 \mu \mathrm{l}$ of hot start premix (Genedirex, Taiwan), $1 \mu \mathrm{l}$ of each of reverse and forward primer (F:5'-CTCCTGGAATCCCAAGTATCAG-3' and R: 5'-GGCAGGTTGAACAGCAGTATCT-3'), which amplify a 237 bp fragment (concentration: $10 \mathrm{pmol}$ ), $2 \mu \mathrm{l}$ of sample DNA (50-150ng/ $\mu \mathrm{l})$, the remainder was filled with $8.5 \mu \mathrm{l}$ nuclease-free water (Qiagen, Germany). The process of amplification was performed in thermocycler $\left(\right.$ GeneAmp ${ }^{\circledR}$ PCR System 9700, Singapore, Applied Biosystems) according to Latif-Eugenín et al. (14). PCR program was $95^{\circ} \mathrm{C}$ for $3 \mathrm{~min}$ followed by 35 amplification cycles of denaturation, annealing and elongation, were $94^{\circ} \mathrm{C}$ for $1 \mathrm{~min}$, $56^{\circ} \mathrm{C}$ for $1 \mathrm{~min}$, and $72^{\circ} \mathrm{C}$ for $1 \mathrm{~min}$, respectively and final elongation of $72^{\circ} \mathrm{C}$ for $5 \mathrm{~min}$. Amplification of PCR products was confirmed in $1.5 \%$ agarose gel prepared with $1 \times$ Trisacetate-EDTA (TAE) buffer and stained by red safe DNA staining solution (GeNetBio, Korea). Successful gcat gene amplification is considered when bands in agarose gel at the anticipated size of 237 bp seen.

\section{Antibiotic susceptibility test}

The identified isolates by PCR assay were tested against 8 antibiotics as described by Stratev and Odeyemi (7) and $\mathrm{Li}$ et al. (15), using the disk diffusion method on MuellerHinton agar (Lab M, UK). The concentration of each antibiotic per disc (Bio-analyze, Turkey) was as follow: doxycycline $30 \mu \mathrm{g}$, trimethoprim-sulfamethoxazole 1.25 and $23.75 \mu \mathrm{g}$, gentamicin $(10 \mu \mathrm{g})$, ciprofloxacin $5 \mu \mathrm{g}$, ceftriaxone $30 \mu \mathrm{g}$, imipenem $10 \mu \mathrm{g}$, levofloxacin $5 \mu \mathrm{g}$ and norfloxacin $10 \mu \mathrm{g}$. The protocol and interpretations of results breakpinots were carried out according to clinical and laboratory standards institute (CLSI) (16). Isolates were marked as either susceptible or resistant isolates that were 
intermediately susceptible to specific antibiotic were classified as resistant. Any isolate that was resistant to three or more antibiotics $(\geq 3)$ was known as multiple antibiotics resistance (MAR).

\section{Results}

\section{Phenotypic methods for the detection of Aeromonas hydrophila}

The cultural characteristics of all isolates of Aeromonas hydrophila on blood agar were found as $\beta$-hemolytic, with grey, flat, round and shiny colonies about 2-3 $\mathrm{mm}$ in diameter. On MacConkey agar, their colonies were showed as pale non lactose fermenter. With Grams stain all isolates were showed as medium-sized, straight, Gram-negative rods under oil immersion objective lens (Figure 1). While the results of biochemical tests, all isolates were indole positive characteristic red ring above fluid media in tryptophan broth, oxidase test positive (the color was changed of cotton swab with a loopful of bacterial culture to dark purple within 10 seconds after adding of $1 \%$ solution of N, N-dimethyl-pphenylenediamine hydrochloride, catalase test positive bubble formation after adding of one drop of hydrogen peroxide on a loopful of bacterial culture on sterile microscopic slide and urease test negativity the color of Christensen's urea agar contained $40 \%$ urea solution was changed to yellowish as a result of acidic byproduct from glucose utilization (Figure 2).

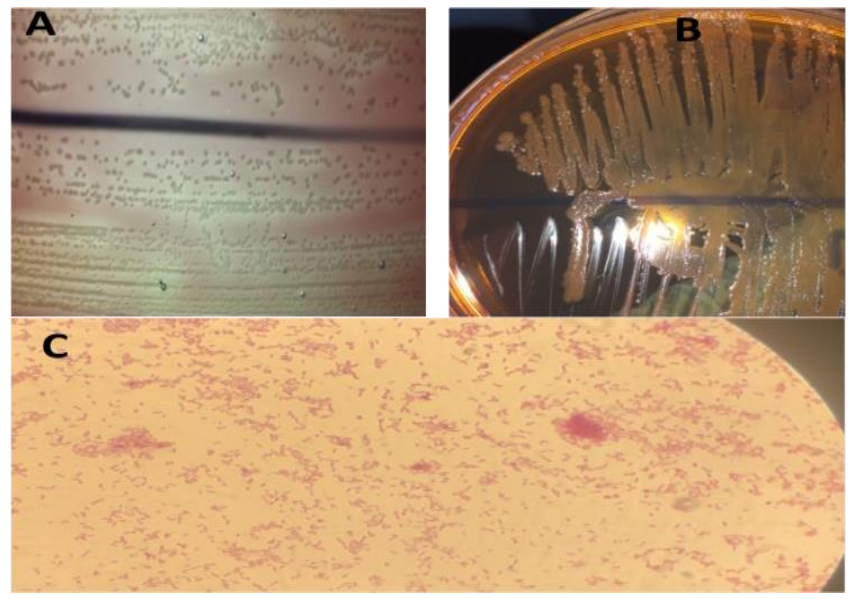

Figure 1: Characteristic $\beta$-hemolytic, round colonies of $A$. hdrophila on blood agar (A); pale (non lactose fermenter) colonies on MacConkey agar (B); Medium-sized, straight, Gram-negative rods (1000x) (C).

\section{Genotypic method for the detection of Aeromonas hydrophila}

According to the PCR amplification of gcat gene, all identified Aeromonas hydrophila isolates by both morphological and biochemical tests, were showed a band size of about $237 \mathrm{bp}$ on agarose gel after staining with red safe DNA staining solution and after electrophoresis process (Figure 3). These were indicated that all isolates were $A$. hdrophila.

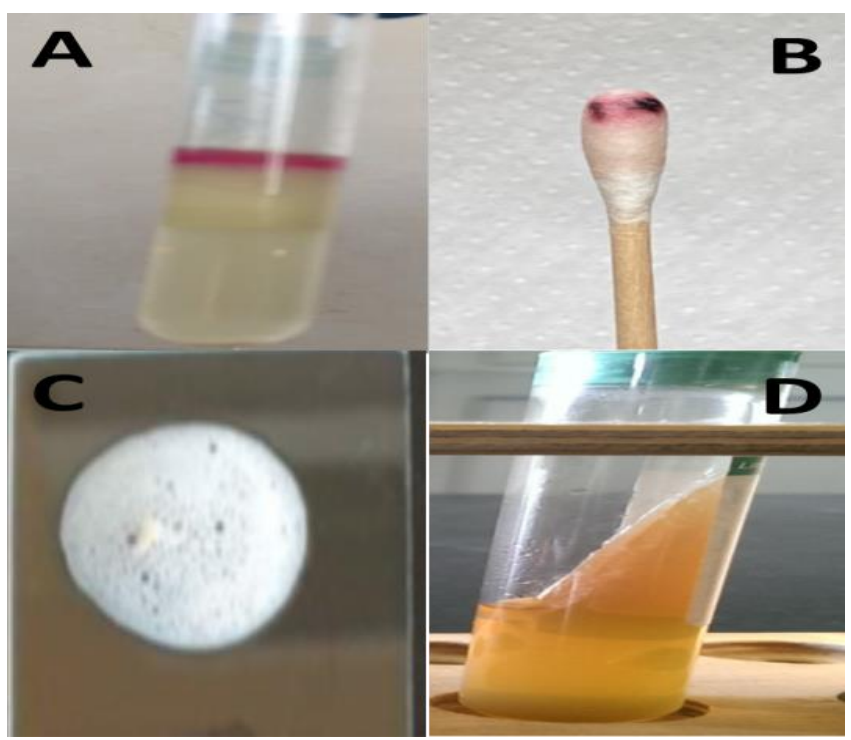

Figure 2: Indole positive (characteristic red ring above fluid media in tryptophan broth) (A); dark purple color formation indicative of oxidase test positive (B); bubble formation indicates of catalase test positivity (C); yellow color of Christensen's urea agar containing $40 \%$ urea indicate urease test negativity (D).

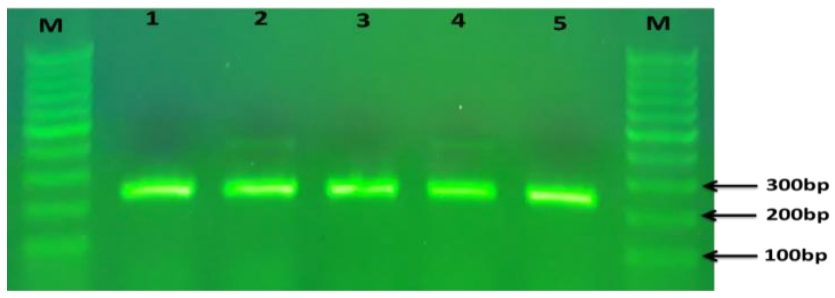

Figure 3: Agarose gel electrophoresis of PCR products. M: $100 \mathrm{bp}$ DNA ladder, lines (1-5) positive result at $237 \mathrm{bp}$ for gcat gene of A. hydrophila isolates.

Out of 25 carp examined, only 19 fish were found to be infected with A. hydrophila. While out of 100 collected organ samples ( 25 livers, 25 kidneys, 25 hearts, and 25 skins) from a total of 25 examined carps, only 24 strains of $A$. hydrophila were identified. These were in accordance with phenotypic methods (Figure 1 and 2) and genotypic methods (PCR amplification of gcat gene) (Figure 3). The liver was the predominated organ to have A. hydrophila (9 isolates) followed by kidney and heart each of (6 isolates) and skin of about (3 isolates) (Table1). Regarding the geographical region, fishes from Khanke area and agricultural pond 3 were 
showed a higher isolation rate $(100 \%)$ followed by Mosul dam (80\%), Agricultural 2 (75\%), and Agricultural 1 (43\%) (Table 1).

\section{Antibiotic susceptibility test}

All isolates were resistant to at least one tested antibiotic. Ninety-six percent of the isolates were found to be resistant to each of imipenem and gentamicin, followed by doxycycline $92 \%, 88 \%$ by each of ciprofloxacin and trimethoprim-sulfamethoxazole, norfloxacin $58 \%$ and ceftriaxone $33 \%$. Neither of the isolates was levofloxacin resistance (all were susceptible) (Figure 4), (Table 2). Twenty-one isolates $88 \%$ were multiple antibiotics resistant (resistant to $\geq 3$ antibiotics) (Figure 4). The MAR was high in agricultural 2 and 3 farms $100 \%$ (Table 2).

Table 1: Isolation rate of $A$. hydrophila in different fish farms

\begin{tabular}{|c|c|c|c|c|c|c|c|}
\hline Geographical region & No of sampled fish & No and $\%$ of positive fish & No of isolates & \multicolumn{4}{|c|}{ Liver Kidney Heart Skin } \\
\hline Agricultural 1 & 6 & $2(43 \%)$ & $3^{\mathrm{a}}$ & 2 & - & - & 1 \\
\hline Agricultural 2 & 4 & $3(75 \%)$ & 6 & 2 & 1 & 1 & 2 \\
\hline Agricultural 3 & 4 & $4(100 \%)$ & 5 & 3 & 1 & 1 & - \\
\hline Mosul dam & 5 & $4(80 \%)$ & 4 & - & 2 & 2 & - \\
\hline Total & 25 & $19(76 \%)$ & $24^{\mathrm{a}}$ & 9 & 6 & 6 & 3 \\
\hline
\end{tabular}

No: number; ${ }^{\text {a: }}$ represent the number of $A$. hydrophila isolates but not the exact percentage of positive fish.

Table 2: Antibiotic-resistant profile of 24 A. hydrophila isolates

\begin{tabular}{|c|c|c|c|c|c|c|c|c|c|}
\hline \multirow{2}{*}{$\begin{array}{l}\text { Geographical } \\
\text { region (No) }\end{array}$} & \multicolumn{9}{|c|}{$\mathrm{N}(\%)$} \\
\hline & IMI & $\mathrm{CFN}$ & CIP & GEN & SXT & NOR & DOX & LEV & MAR \\
\hline Agricultural 1 (3) & $2(67 \%)$ & $1(33 \%)$ & $2(67 \%)$ & $2(67 \%)$ & $2(67 \%)$ & $1(33 \%)$ & $3(100 \%)$ & - & $2(67 \%)$ \\
\hline Agricultural 2 (6) & $6(100 \%)$ & $2(33 \%)$ & $6(100 \%)$ & $6(100 \%)$ & $5(83 \%)$ & $3(50 \%)$ & $6(100 \%)$ & - & $6(100 \%)$ \\
\hline Agricultural 3 (5) & $5(100 \%)$ & $2(40 \%)$ & $5(100 \%)$ & $5(100 \%)$ & $5(100 \%)$ & $3(60 \%)$ & $5(100 \%)$ & - & $5(100 \%)$ \\
\hline Khanke (6) & $6(100 \%)$ & $2(33 \%)$ & $5(83 \%)$ & $6(100 \%)$ & $5(83 \%)$ & $4(67 \%)$ & $5(83 \%)$ & - & $5(83 \%)$ \\
\hline Mosul dam (4) & $4(100 \%)$ & $1(25 \%)$ & $3(75 \%)$ & $4(100 \%)$ & $4(100 \%)$ & $3(75 \%)$ & $3(75 \%)$ & - & $3(75 \%)$ \\
\hline 24 isolates & $23(96 \%)$ & $8(33 \%)$ & $21(88 \%)$ & $23(96 \%)$ & $21(88 \%)$ & $14(58 \%)$ & $22(92 \%)$ & - & $21(88 \%)$ \\
\hline
\end{tabular}

IMI: imipenem, CFN: ceftriaxone, CIP: ciprofloxacin, GEN: gentamicin, SXT: trimethoprim-sulfamethoxazole, NOR: norfloxacin, DOX: doxycycline, LEV: levofloxacin, MAR: Multiple antibiotics resistance. No: number.

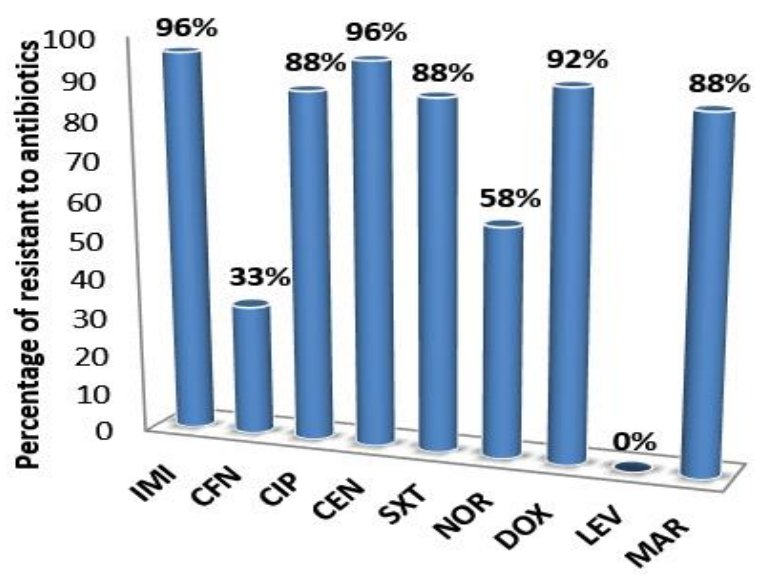

Figure 4: Antibiotic-resistant profile a total of $24 \mathrm{~A}$. hydrophila isolates to different tested antibiotics. IMI: imipenem, CFN: ceftriaxone, CIP: ciprofloxacin, GEN: gentamicin, SXT: trimethoprim-sulfamethoxazole, NOR: norfloxacin, DOX: doxycycline LEV: levofloxacin, MAR: Multiple antibiotics resistance.

\section{Discussion}

Aeromonas hydrophila is a significant opportunistic pathogen in the aquatic environment of freshwater where the most critical stressors include rough handling, crowding, malnutrition, heavy free ammonia $\left(\mathrm{NH}_{3}\right)$ and elevated nitrites $\left(\mathrm{NO}_{2}\right)$ are present $(1,8)$. Adding to these, in muddy water with heavy organic content, $A$ hydrophila is abundant (17). Any changes in water parameters can lead to immune stress situations and this will predispose fish from being infected with $A$. hydrophila, and encourage opportunist bacterial infections $(1,18)$. The high isolation rate of $A$. hydrophila seen in this study can all be due to these factors. However, in this study, not all fish showing clinical signs of septicemia were harbored $A$. hydrophila, this mostly due to that a large number of Aeromonas spp other than hydrophila are responsible for hemorrhagic septicemia in fish. There is strong evidence that many Aeromonas spp as a cause of diseases have been found in aquatic environments (wild and farmed fresh water and/or marine species) (19). The causes of epizootic ulceration and hemorrhagic septicemia in fishes have become well established with Aeromonas veronii (8). 
In another study which was carried in China, proposed that motile Aeromonas spp. other than A. hydrophila were also found in moribund fish with hemorrhagic septicemia (17).

According to the clinical and laboratory standards institute CLSI (16) isolates that are initially susceptible or intermediately resistant to one antibiotic may become resistant after initiation of therapy. Therefore, in this study any isolate that was intermediately resistant to specific antibiotic was classified as resistant isolate to antibiotics. In this study, all the isolates showed a high degree of resistance to the tested antibiotics with a significant resistance to both imipenem and gentamicin. However, Sreedharan et al. (20), reported a total sensitivity of Aeromonas spp., to imipenem and gentamicin. As well as, Al-Dabbagh (21) in Mosul, Iraq, also found that $A$. hydrophila isolated from milk samples in bovine mastitis was susceptible to gentamicin. On the other hand, Stratev and Odeyemi (7) reported that 50\% of $A$. hydrophila isolated from Tilapia were resistant to imipenem. This finding most likely reflects the presence of selective pressures in these ecosystems mainly because antimicrobial agents are used in both aquatic and human clinical prevention and treatment strategies $(15,22)$. However, imipenem has never been used neither therapeutically nor prophylactically in an aquatic environment but the resistant in these fields is most likely created due to human wastewaters (hospital wastewaters) or rivers containing imipenem resistant genes (carbapenems) or antibiotic residues with subsequent contamination to the aquatic environment which in turn lead to the development of selective pressure of resistant in these environments $(23,24)$. In a study carried out to explore the existence of antibiotic resistance in hospitals wastewater collected in Mumbai, India, identified new resistance genes and novel carbapenemases including NDM, VIM, IMP, KPC, and OXA-48 (25). In comparison, all isolates were levofloxacin susceptible in this study and this is consistent with Li et al. (15). This indicates that this antibiotic is not yet used in aquatic environments as a therapeutic or prophylactic purpose.

An alarming level of MAR in this work was observed especially in isolates from Agricultural 2 and 3. This indicates that in these farms different antibiotic types were used as a prophylactic purpose to reduce the probability of the occurrence of infectious diseases or to accelerate aquaculture growth $(24,26)$. The presence of bacteria in overcrowding microbial ecosystems favorable for the transfer of genetic materials such as plasmid, transposons, and integrons carrying multiple antimicrobial-resistant genes is usually regarded a reason for MAR development (27) or that isolates carried genes codes for efflux pumps to multiple antibiotics, resulting to the higher rates of MAR (28). The presence of MAR in A. hydrophila has also been reported by others $(7,22,29)$.

\section{Conclusion}

A high isolation rate of A. hydrophila found in this study, means that this is a common organism associated with disease outbreaks in aquaculture in the Dohuk province, Iraq. This indicates that $A$. hydrophila is a primary invader in farmed fish in our area. The high levels of antibiotic resistance recorded in this study should be carefully considered as these isolates can serve as a human source of infection during food series and pose a major challenge for the therapeutic possibility.

\section{Acknowledgments}

This study was partially supported by the College of Veterinary Medicine, University of Duhok, Iraq. Great thanks to the College of Agriculture for providing the samples and to Duhok Research Centre (DRC) for works facility. Thanks are extended to Dr. Rezheen F Abdurrahman for work advice.

\section{Conflict of interest}

The authors declare that there are no conflicts of interest regarding the publication of this manuscript

\section{References}

1. Pękala-Safińska A. Contemporary threats of bacterial infections in freshwater fish. J Vet Res. 2018;62(3):261-7. Doi: 10.2478/jvetres2018-0037

2. Aboyadak IM. Molecular detection of Aeromonas hydrophila as the main cause of outbreak in tilapia farms in Egypt. J Aquac Mar Biol. 2015;2(6):2-5. Doi: 10.15406/jamb.2015.02.00045

3. Janda JM, Abbott SL. The genus Aeromonas: Taxonomy, pathogenicity, and infection. Clin Microbiol Rev. 2010;23(1):35-73. Doi: 10.1128/CMR.00039-09

4. Spadaro S, Berselli A, Marangoni E, Romanello A, Colamussi MV, Ragazzi R, Zardi S, Volta CA. Aeromonas sobria necrotizing fasciitis and sepsis in an immunocompromised patient: A case report and review of the literature. J Med Case Rep. 2014;8(1):1-6. Doi: 10.1186/17521947-8-315

5. Abbott SL, Cheung WKW, Janda JM. The genus Aeromonas: Biochemical characteristics, atypical reactions, and phenotypic identification schemes. J Clin Microbiol. 2003;41(6):2348-57. Doi: 10.1128/JCM.41.6.2348-2357.2003

6. Miñana-Galbis D, Farfán M, Lorén JG, Fusté MC. Biochemical identification and numerical taxonomy of Aeromonas spp. isolated from environmental and clinical samples in Spain. J Appl Microbiol. 2002;93(3):420-30. Doi: 10.1046/j.1365-2672.2002.01711.x.

7. Stratev D, Odeyemi OA. Antimicrobial resistance of Aeromonas hydrophila isolated from different food sources: A mini-review. J Infect Public Health. 2016;9(5):535-44. Doi: 10.1016/j.jiph.2015.10.006

8. Hassan MA, Noureldin EA, Mahmoud MA, Fita NA. Molecular identification and epizootiology of Aeromonas veronii infection among farmed Oreochromis niloticus in Eastern Province, KSA. Egypt J Aquat Res. 2017;43(2):161-7. Doi: 10.1016/j.ejar.2017.06.001

9. Zubairi RB. Genetic detection to Aeromonas hydrophila proteolytic activity in milk samples (cows, buffaloes and goats) in Basra governorate. Iraqi J Vet Sci. 2020;34(2):253-8. Doi: $\underline{10.33899 / \text { ijvs.2019.125888.1174 }}$ 
10. Chacón MR, Castro-Escarpulli G, Soler L, Guarro J, Figueras MJ. A DNA probe specific for Aeromonas colonies. Diagn Microbiol Infect Dis. 2002;44(3):221-5. Doi: 10.1016/s0732-8893(02)00455-8

11. Taha ZM, Yassin NA. Prevalence of diarrheagenic Escherichia coli in animal products in Duhok province, Iraq. Iran $\mathrm{J}$ Vet Res. 2019;20(4):255-62. Doi: 10.22099/ijvr.2019.5502

12. Hado HA, Assafi MS. Molecular fingerprinting of methicillin resistant Staphylococcus aureus strains isolated from human and poultry in Duhok, Iraq. Iraqi J Vet Sci. 2021;35(1):99-103. Doi: 10.33899/ijvs.2020.126375.1310

13. Hussein SA. S Study of Staphylococcus aureus isolated from the mouth of canary. Iraqi J Vet Sci. 2020;34(2):301-4. Doi: 10.33899/ijvs.2019.125937.1192

14. Latif-Eugenín F, Beaz-Hidalgo R, Figueras MJ. A culture independent method for the detection of Aeromonas species. From water samples. Ital J Food Saf. 2016;5(1):11-4. Doi: 10.4081/ijfs.2016.5489

15. Li F, Wang W, Zhu Z, Chen A, Du P, Wang R, Chen H, Hu Y, Li J, Kan B, Wang D. Distribution, virulence-associated genes and antimicrobial resistance of Aeromonas isolates from diarrheal patients and water, China. J Infect. 2015;70(6):600-8. Doi: 10.1016/j.jinf.2014.11.004

16. Clinical and laboratory standards institute. M100-S25 Performance standards for antimicrobial. Wayne. 2015;35(3):1-236.

17. Nielsen ME, Hi L, Schmidt AS, Qian D, Shimada TJ, Larsen JL. Is Aeromonas hydrophila the dominant motile Aeromonas species that causes disease outbreaks in aquaculture production in the Zhejiang Province of China? Dis Aquat Organ. 2001;46(1):23-9. Doi: 10.3354/dao046023

18. Iregui CA, Comas J, Vásquez GM, Verjan N. Experimental early pathogenesis of Streptococcus agalactiae infection in red tilapia Oreochromis spp. J Fish Dis. 2016;39(2):205-15. Doi: $\underline{10.1111 / \mathrm{jfd} .12347}$

19. Chaix G, Roger F, Berthe T, Lamy B, Jumas-Bilak E, Lafite R, ForgetLeray R, Petit F. Distinct Aeromonas populations in water column and associated with copepods from estuarine environment (Seine, France). Front Microbiol. 2017;8:1-13. Doi: 10.3389/fmicb.2017.01259

20. Sreedharan K, Philip R, Singh ISB. Virulence potential and antibiotic susceptibility pattern of motile aeromonads associated with freshwater ornamental fish culture systems: A possible threat to public health. Brazilian J Microbiol. 2012;43(2):754-65. Doi: 10.1590/S151783822012000200040

21. Al-Dabbagh SYA. Bovine mastitis caused by gram negative bacteria in $\begin{array}{llll}\text { Mosul. Iraqi J Vet Sci. 2012;26(1):11-6. Doi: } & \end{array}$ 10.33899/ijvs.2012.35193

22. Zdanowicz M, Mudryk ZJ, Perliński P. Abundance and antibiotic resistance of Aeromonas isolated from the water of three carp ponds. Vet Res Commun. 2020;44(1):9-18. Doi: 10.1007/s11259-020-09768$\underline{\mathrm{X}}$

23. Al-Mashhadany DA. Monitoring of antibiotic residues among sheep meats at Erbil city and thermal processing effect on their remnants. Iraqi J Vet Sci. 2020;34(2): 217-222. Doi: 10.33899/ijvs.2019.125814.1161

24. Marathe NP, Janzon A, Kotsakis SD, Flach CF, Razavi M, Berglund F, Kristiansson E, Kristiansson E, Larsson DGJ. Functional metagenomics reveals a novel carbapenem-hydrolyzing mobile beta-lactamase from Indian River sediments contaminated with antibiotic production waste. Environ Int. 2018;112: 279-86. Doi: 10.1016/j.envint.2017.12.036

25. Ma Marathe NP, Berglund F, Razavi M, Pal C, Dröge J, Samant S, Kristiansson E, Larsson DGJ. Sewage effluent from an Indian hospital harbors novel carbapenemases and integron-borne antibiotic resistance genes. Microbiome. 2019;7(1):1-11. Doi: 10.1186/s40168-019-0710-x
26. Miranda CD, Godoy FA, Lee MR. Current status of the use of antibiotics and the antimicrobial resistance in the chilean Salmon farms. 2018;9:1-14. Doi: 10.3389/fmicb.2018.01284

27. Economou V, Gousia P. Agriculture and food animals as a source of antimicrobial-resistant bacteria. Infect Drug Resist. 2015;8: 49-61. Doi: 10.2147/IDR.S55778

28. El-Sharkawy H, Tahoun A, El-Gohary AEGA, El-Abasy M, El-Khayat F, Gillespie T, Kitade Y, Hafez HM, Neubauer H, El Adawy H. Epidemiological, molecular characterization and antibiotic resistance of Salmonella enterica serovars isolated from chicken farms in Egypt. Gut Pathog. 2017;9(1):1-12. Doi: 10.1186/s13099-017-0157-1

29. Vivekanandhan G, Savithamani K, Hatha AAM, Lakshmanaperumalsamy P. Antibiotic resistance of Aeromonas hydrophila isolated from marketed fish and prawn of South India. Int J Food Microbiol. 2002; 76:165-168. Doi: 10.1016/S0168$\underline{1605(02) 00009-0}$

\section{بحث عن جين gcat ونمط المقاومة للمضادات الحيوية

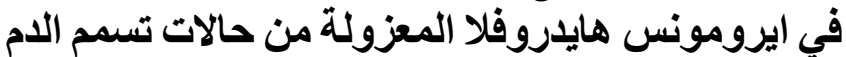 النزفية في المزئونية هائرع السمكية}

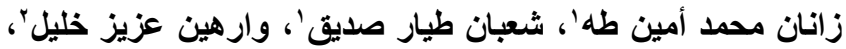

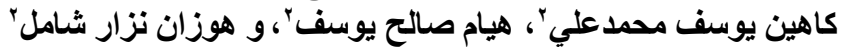

الطب الأمر اض و الأحياء المجهرية، بقسم الطب الباطني و الجر احة، كلية الخلاصة

الهدف من الدراسة هو بحث أهمية ايرومونس هايدروفلا والعلاقة

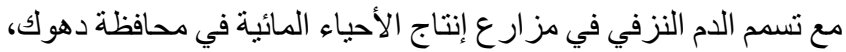

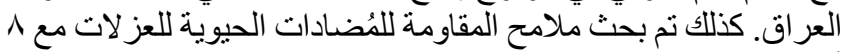

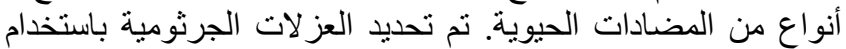
الاختبارات المظهرية والاختبارات الكيميائية الحيوية وقد تم تأكيدها

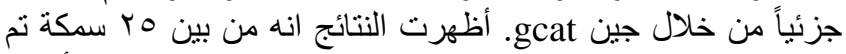

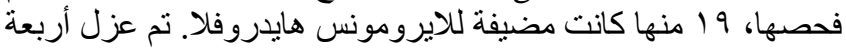

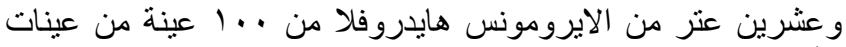

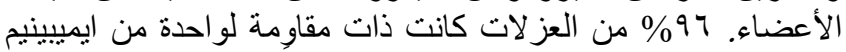

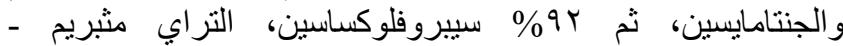

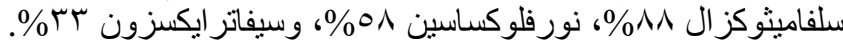

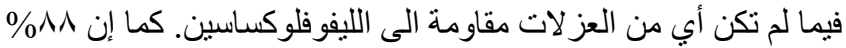

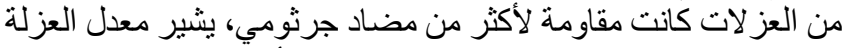

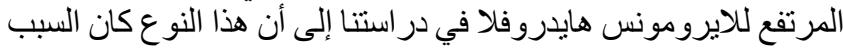

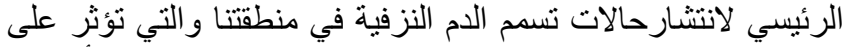

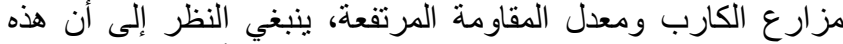

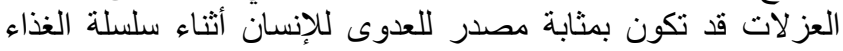
ونشكل تحديًا كبير الفرصهم العلاجية. 